\title{
MUNICIPAL SOLID WASTE MANAGEMENT IN TARKWA AREA COUNCIL (TAC), GHANA
}

\author{
VICTORIA ELORM FREMPONG \\ Department of Mineral Engineering, University of Mines and Technology, Tarkwa, Ghana.
}

\begin{abstract}
Effective municipal solid waste (MSW) management rids a community of filth and makes it healthy for human habitation. However, it is notably missing in several parts of Ghana as evidenced by low coverage and irregular waste collection services and an unconcerned public attitude towards waste disposal. The situation is exemplified in the Tarkwa Area Council (TAC), a mining community in Ghana. Lack of data on waste generation, storage, transfer and transportation and disposal in the area makes MSW management very difficult. The objectives of this research, therefore, are to investigate how MSW is managed in TAC, identify short falls and make appropriate recommendations for improvement. Questionnaires were given to 420 residents in the municipality focusing on their background, major environmental concerns, current waste disposal practices and their perspectives of general waste management. Air pollution, inadequate waste collection and unsafe waste disposal were the major environmental concerns of the residents. Food remains, sweepings and plastics are the major types of waste produced. About $45.5 \%$ of residents were not satisfied with the level of MSW management in TAC. Waste is not separated at source and hence, not subjected to recycling. The final waste disposal site is not engineered and is operated as a dump.

Keywords: Landfill, municipal waste, solid waste, Tarkwa, waste dump, waste management.
\end{abstract}

\section{INTRODUCTION}

Ever since humans stopped living nomadic life, solid waste management became necessary with the main focus of removing waste from immediate human settlements. Simple waste management strategies such as isolation in waste piles, uncontrolled incineration, and disposal in rivers, lakes and oceans were successfully employed because the waste generated was mostly biodegradable and within nature's capacity to nullify the potential impact [1]. However, increasing technological and scientific advancements have resulted in greater complexity and toxicity of waste, with increasing urban population and improvements in standards of living also contributing markedly to increasing volume of waste. These rapid developments have been detrimental to nature's capacity to nullify waste substances effectively, leading to the enactment of policies all over the world on sustainable management of solid waste to enhance the physical environment and/or at least maintain developmental opportunities and approaches available to future generations to have a desirable quality of life [2]. In the 1880s, the United Kingdom introduced policy measures to curb indiscriminate waste disposal by passing the Urban Sanitary Act that prohibited the throwing of solid waste into ditches, rivers and waters [3]. Germany in 1900 also enacted the Federal Epidemic Act in response to pollution by private waste disposal activities [4]. Almost a century later at the United Nations Conference on the Environment and Development in 1992, many nations across the globe agreed to be guided by the principles of sustainability in national policy development to address local, national and international problems including waste management [5].

Municipal solid waste (MSW), also called urban solid waste, predominantly includes household waste and sometimes commercial waste collected by a municipality within a given area. It is in either solid or semi-solid form and generally excludes industrial hazardous waste. MSW management, therefore, is the act of controlling solid waste generation, storage, collection, transfer and transport, processing and disposal in a manner that accords with the best principles and practice of 
public health, economics, engineering, conservation, aesthetics and other environmental considerations and that is also responsive to public attitudes [3]. Improper management of waste has serious health and environmental implications on humans and the ecosystem. Waste disposal on land has the potential of contaminating not only the land, but also in many instances, surface water and ground water basin sources. Land disposal of waste also encourages the breeding of pests, vectors and insects, which carry and transmit various diseases. Foul odour and litter are also nuisance to those living in the vicinity of waste disposal sites.

Among the European Union member countries, there are initiatives, such as the landfill directives (1999/31/EC and 2003/33/EC), aimed at providing measures, procedures and guidance to prevent or reduce negative effects of waste on the environment, in particular, the pollution of surface water, groundwater, soil and air, and on the global environment, including the greenhouse effect as well as any resulting risk to human health, from landfilling of waste, during the whole life cycle of a landfill [6]. Directives like these help to ensure good sanitation in Europe. The same cannot be said for the situation in developing countries including Ghana. There is low coverage of waste collection services and irregular waste collection from communal waste containers/bins and worst of all, there is an unconcerned public attitude towards waste disposal. These factors together contribute to improper waste disposal practices in an environmentally unfriendly manner (e.g. open fire burning and reckless waste dumping). These arise because of unenforced or relaxed regulations on solid waste management in Ghana. There is, for example, a 'Ghana Landfill Guidelines 2002' document but only one properly engineered landfill has been built in the country so far [7]. In addition, there is a lack of local or national initiative to turn waste into a resource to encourage individuals to play active roles in MSW management activities.

Although TAC is a mining community that hosts a number of visitors and mine workers from all over the world throughout the year, the poor state of MSW management in TAC is similar to the situation in other parts of Ghana. Waste is discarded anywhere and waste bins are always overflowing due to irregular collection. Attitudes towards waste disposal are so poor that people discard waste beside waste containers even though they may be empty. These unfortunate practices have led to the creation of several uncontrolled open waste dumps and littering, resulting in foul odour and diseases in the area. Lack of reliable, systematic data on waste generation, storage, transfer and transportation and disposal in the area makes waste management very difficult for the authorities.

The objectives of this research, therefore, are to (1) investigate how MSW is currently managed by individuals and by the Tarkwa-Nsuaem Municipality (TNM) that is responsible for waste management in TAC, (2) identify shortfalls in these MSW management systems practiced in TAC and (3) make appropriate recommendations for better management. The findings of this research will be very useful to TNM in developing proper and effective waste management systems.

TAC is one of the prominent gold mining areas in Ghana. It is located in the Western region of Ghana and about $300 \mathrm{~km}$ west of the capital city Accra $\left[4^{\circ} 50^{\prime} \mathrm{N}\right.$ (latitude) and $2^{\circ} 10^{\prime} \mathrm{W}$ (longitude)]. It is approximately $160 \mathrm{~m}$ above sea level. It covers an area of $2354 \mathrm{~km}^{2}$ and has a population of about 40397 as of 2005 [8]. TAC is one of six area councils under the management of TNM Assembly. The only university in the Western Region of Ghana, University of Mines and Technology (UMaT) is located in Tarkwa, a suburb in TAC as shown in Fig. 1. Access to the area is by asphalt roads from Accra through Takoradi and from Kumasi. The road from Kumasi through Obuasi is tarred and in good condition but that from Obuasi through Dunkwa-on-Offin to TAC is in a very poor state. It can also be accessed by railroad from the twin cities: Sekondi-Takoradi (the harbour city) in the western part of Ghana. The geological formation underlying the area is the Tarkwaian group and the landscape is undulating. A tropical and humid climate pertains in the area because it is located in the transition zone between the high rain forest (very humid) zone and 


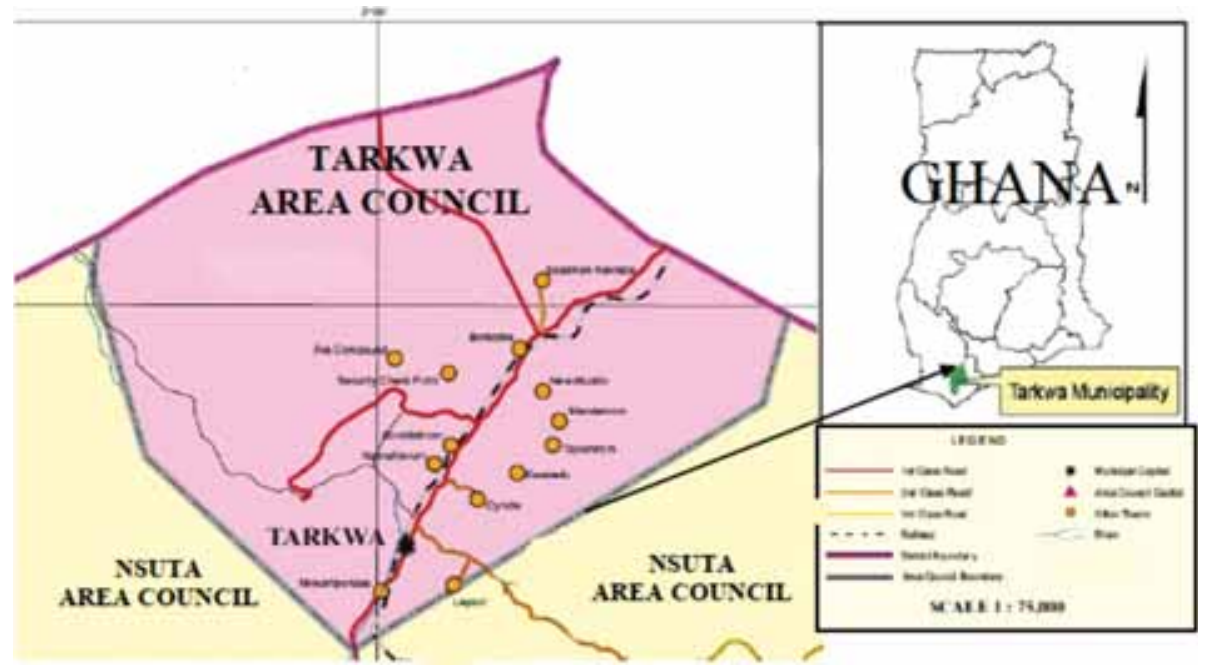

Figure 1: Tarkwa area council (TAC) modified after [8].

the moist semi-deciduous rain forest (humid) zone. The principal rivers in the area are the Huni, Sumang, Awunaben, Bediabewu and Kawere [8]. TAC has 14 towns, which includes the people of Wassa (the indigenous people) and people from all over Ghana, because of the mining activities in the area. The Wassa people and the outsiders live homogeneously in peace in all the suburbs and towns.

\section{METHODOLOGY}

The research design was a cross-sectional survey and the sampling frame included all the 14 towns of TAC. Fourteen suburbs and/or towns were randomly selected for the study. They were Teberebie, Nsuta, Atuabo, Tarkwa, Samahu, Kwabedu, Peterson Hill, Brenu Akyenmu, Taylorkrom, Asaman Ketewa, Boborbo, Bokekrom, Abonti and Bogre. The elements of this sampling frame are individuals and the TNM Assembly. All the mining companies and hospitals in TAC collect and manage all types of waste generated within their facilities on-site, hence individuals and TNM were the two elements selected. The local authority for waste management in TAC is the TNM Assembly. The data for this study are both quantitative and qualitative. The quantitative data were gathered through MSW characterisation while the qualitative sources of data for the research were achieved through questionnaire distribution to individuals, interviews with environmental officers of the TNM Assembly and field visits.

In a survey research, a major subgroup of the sample could be adequately represented by 10 cases and a minor subgroup by 20-50 cases [9]. In this study, 30 cases were considered in each of the 14 suburbs giving a total sample size of 420 . Stratified sampling was used to select the respondents. The subpopulations that formed the strata are the 14 suburbs selected for the study. Questionnaires were given to one individual in every other household, institution, farm or business premises and to every fifth person in the markets or bus stations until all the 30 questionnaires allocated to a suburb are exhausted.

A closed-ended questionnaire (both ordinal- and nominal-polytomous) divided into three sections was used. The sections were background information of respondents (sex, age, level of education, 
location, occupation and monthly income), major environmental issues in TAC [air pollution, unsafe drinking water, insufficient water supply, inadequate sanitation (sewerage), inadequate solid waste collection (SWC) and unsafe solid waste disposal (SWD)] and MSW management (types of storage containers, rate and place of disposal, treatment methods and who does it, household separation, reuse, sale, effects of MSW on the environment and health, willingness to pay for better management, and rating of MSW management in households and the neighbourhood).

Respondents were generally asked the questions on the questionnaire verbally and their answers were transcribed. This was because of anticipated difficulties such as the low probability of respondents completing the questionnaire on their own and the likelihood of not encountering the same people on the day of collection. In addition, in a country with $65 \%$ literacy rate [10], most of the respondents may not be able to read nor write, causing them to ignore the questionnaires. However, respondents who wanted to fill in the questionnaires by themselves were allowed to do so and the questionnaire was taken immediately after.

Waste is a concern for everyone living in a community; therefore, the views of every member of the community are important. This survey therefore considered all respondents at random irrespective of their level of literacy. In cases where the respondents did not understand English, questions were asked in the native Wassa or Akan language and the answer was translated into English before transcription. Although the respondents spoke different native dialects depending on which part of Ghana they come from, they were all able to speak Akan, probably because they had settled in TAC for some time.

The selected approach used for the waste characterisation was waste generator sampling. This method of sampling was used because of the lack of information on the current final waste disposal site and the non-existence of data on waste characterisation in TAC. These disadvantages made it impossible to use the landfills sampling method and any other prescribed method of sampling waste [11]. Routine observations by the author revealed that the types and quantities of waste generated by the people is virtually the same throughout the year. However, the quantity varies on daily basis because of the lifestyle of the people. Samples were therefore taken for a period of 1 week.

At least three households in each suburb, two institutions and six commercial centres within TAC were randomly selected to participate in the exercise giving a total of 54 samples collected daily. Members of each candidate household were educated on the importance of the project and those willing to participate were given eight thin plastic bags to store each day's waste for 8 consecutive days. The first day's samples collected were directly discarded as they could contain waste from previous days. A total of 12 groups of MSW were identified based on the information gathered in the survey and the nature and types of waste generated in TAC. The waste groups are textiles, paper, ceramics, plastics, leather, food remains, grass, wood, metals, glass, sweepings and a miscellaneous group. The California Integrated Waste Management Board suggests at least 30 samples for residential waste [12].

All sorting was conducted in a designated area off the collection points, an isolated open place approximately $10 \mathrm{~m} \times 10 \mathrm{~m}$ in size. Once samples were offloaded from the vehicle, each bag collected was first weighed and then its content emptied into a 200-L graduated bucket to measure the volume after a moderate compaction. The content of each bucket was then spread over a specially designated sorting floor lined with a thin plastic sheet. At the sort floor, which was covered by a 0.5-in. screen, MSW was hand sorted into 12 labelled bowls. Bagged or boxed materials were opened and all wastes were sorted. Sorting continued until the screen was cleared of material and the layer of fines beneath the screen was placed in a 'sweepings' bowl. Special effort was made to totally separate all waste above the screen into the component material categories and remove or shake off to the appropriate category as much contamination (grit and moisture) as possible. 
Environmental officers from the TNM Assembly were interviewed on how the assembly is managing MSW in TAC and visits were made to their waste management facilities.

\section{RESULTS}

\subsection{Background of respondents}

Out of the 420 respondents, $63.8 \%$ were females and $36.2 \%$ were males. The average age of the younger group of respondents was 17 years and that of the older group was 62 years.

Majority of the repondents were junior secondary school (JSS) graduates followed by senior secondary school (SSS) and middle schools form four graduates. About $11 \%$ of the respondents had tertiary education probably due to the presence of UMaT. However, about $9 \%$ of the repondents did not have formal education (Fig. 2) and they were mostly from Samahu, Boborbo, Asamanketewa, Bogre and Taylorkrom.

Alhough the respondents were randomly selected within the suburbs, $75 \%$ of them were in homes, especially in suburbs other than Tarkwa where all commercial activities are centred in the municipality. About $21 \%$ were located in business premises, made up of $8 \%$ in provision or clothing shops, $4 \%$ in tailoring, $2 \%$ in salons and the hospitality industry, $1 \%$ in carpentry, welding and electronic shops and $4 \%$ in other locations [quarry, corn mill, Ghana Private Road Tranport Union office, galamsey and palm kennel oil extraction sites]. About $1 \%$ were located in instituitions (University, JSS and primary schools, banks and other government establishments), markets, bus stations and farms. Majority of the respondents were engaged in buying and selling and about $3.3 \%$ were in the service provision sector while about $10.2 \%$ were unemployed. Those unemployed were mostly from Kwabedu (majority), Samahu, Teberebie and Atoabo. None of the respondents were unemployed in Nsuta.

Ghanaians normally do not disclose their income to people, not even to their nuclear family. Hence only $36 \%$ of the respondents answered the question on monthly income and out of this percentage, about $33.6 \%$ of them earn between GH $\phi 1$ and 300 (US\$157.9) per month, $1.9 \%$ between Gh $\varnothing 301$ and 600 (US\$ 315.8) and 0.5\% between Gh $\varnothing 600$ and 1000 (US\$ 526.3) per month. There

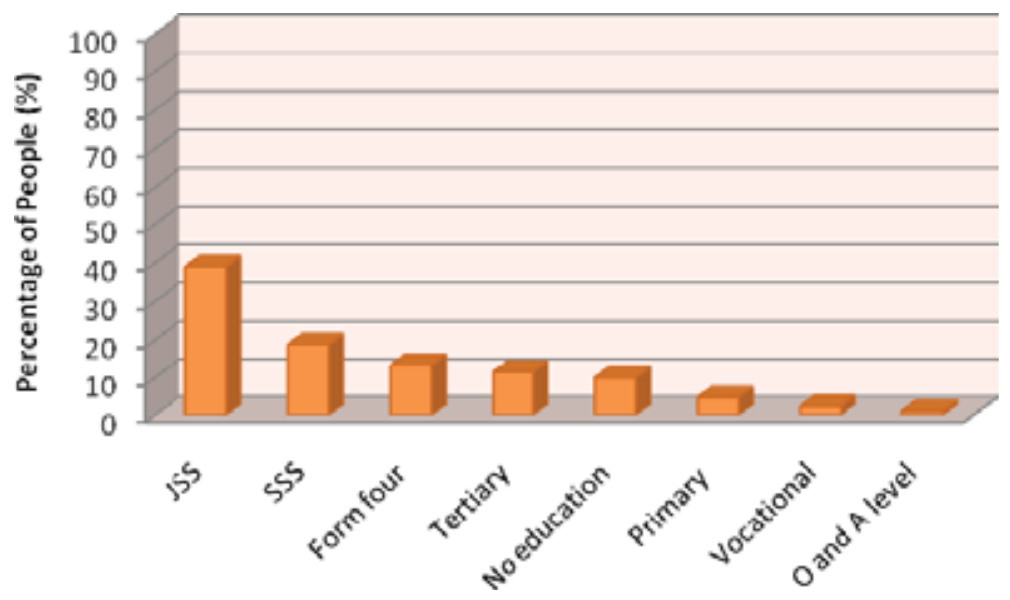

Figure 2: Highest level of education in TAC. 
are workers in the town who may earn more than $1000 \mathrm{GH} \phi$ per month but they are probably part of the $64 \%$ who prefer to keep their salaries a secret.

\subsection{Major concern}

When the respondents were questioned about the most prominent environmental issue facing the town, majority (24.3\%) of them said it was air pollution. Air pollution is the most talked about problem in the town especially in suburbs like Teberebie and Nsuta, which are mining communities. Respondents in Tarkwa, Kwabedu and Asamanketewa, though comparatively not very close to any mine, also complained about air pollution due to the poor state of roads in the town. Atoabo is closer to a mine but the inhabitants did not complain about air pollution because the mining company waters the untarred roads in the community every morning and evening. Inadequate SWC and unsafe SWD were priority two and three problems, respectively, as shown in Fig. 3. MSW is an eyesore on the streets just like in some other places in Ghana. Solid waste, especially plastics, litter everywhere in the suburbs. Individuals dispose of unwanted items indiscriminately without any consideration to the environment. It is also observed that people discard waste beside waste containers instead of inside it and though the municipal assembly and a private waste management company (Zoomlion Ghana Ltd) collect waste from designated points, the waste bins are always overflowing, making the collection points look like waste dumps. Apart from air pollution and solid waste issues being the first three prorities in TAC in general, some towns like Atoabo, Samahu, Boborbo, Taylorkrom, Bogre and Brenu Akyemu have unsafe drinking water and insufficient water supply as their priority one problem.

\subsection{Solid waste management}

\subsubsection{Waste composition and temporal storage}

The goal of this research was to determine the MSW management practice in TAC and hence propose a sustainable system to manage it. This involves investigating the composition of waste

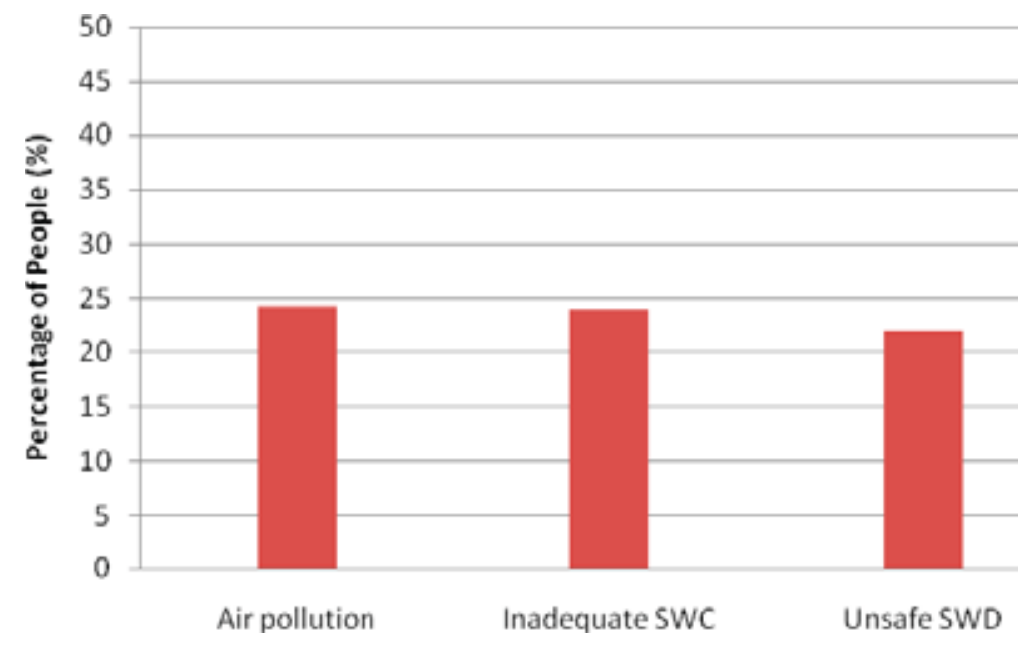

Figure 3: Major environmental concerns in TAC. 
generated in TAC. By ascertaining the major waste types produced by the public, measures aimed at addressing MSW problems can focus more on these types of waste. From the waste characterisation, the major waste types produced by the respondents are food remains (32\%), sweepings (22\%) and plastics $(16 \%)$. The percentage composition of waste in TAC is presented in Fig. 4. The findings of this study are similar to what is happening in the rest of Ghana and other developing countries in Africa. According to Palczynski [13], waste generated in developing countries contains food remains as the largest fraction, ranging between 35\% and 80\%. Palczynski [13] also reported in 2002 that plastics constitute about $10 \%$ of the total waste. It is believed the use of plastics is on the increase in developing countries, and in this work, $16 \%$ of the wastes produced are plastic based. Interviews conducted by Babanawo [14] in 2006 in Ghana with members of parliament and the general public showed that most people perceived plastics as the most problematic waste in the country.

Respondents from all the suburbs produce more food remains except for those living in Samahu, Taylorkrom and Bokekrom, who generate more sweepings than food remains. About $90 \%$ of people from Tarkwa suburb mentioned plastic waste as one of the major waste they produce while only $10 \%, 16.6 \%$ and $33.3 \%$ respondents produce plastic waste in Asamanketewa, Atoabo and Samahu, respectively. This is not surprising as Tarkwa is the commercial centre of the municipality. Suburbs such as Samahu, Taylorkrom, Teberebie and Asamanketewa, where roads are not tarred, produce more sweepings.

About $65.7 \%$ of the respondents store waste in thick plastic containers, $9.3 \%$ in thin plastic bags, $5.5 \%$ in metal containers including buckets, $2.6 \%$ in woven baskets and $1.2 \%$ in cartons while $15.7 \%$ of respondents store it in sacks and any container available.

\subsubsection{Rate and place of waste disposal}

About $24 \%$ of the respondents dispose of waste immediately while $64 \%$ of them do it daily. About $5 \%, 3 \%$ and $3 \%$ dispose them thrice, twice and once in a week, respectively. When asked about the place of disposal, about $67.9 \%$ of respondents said at open waste dumps in the communities, $10.7 \%$

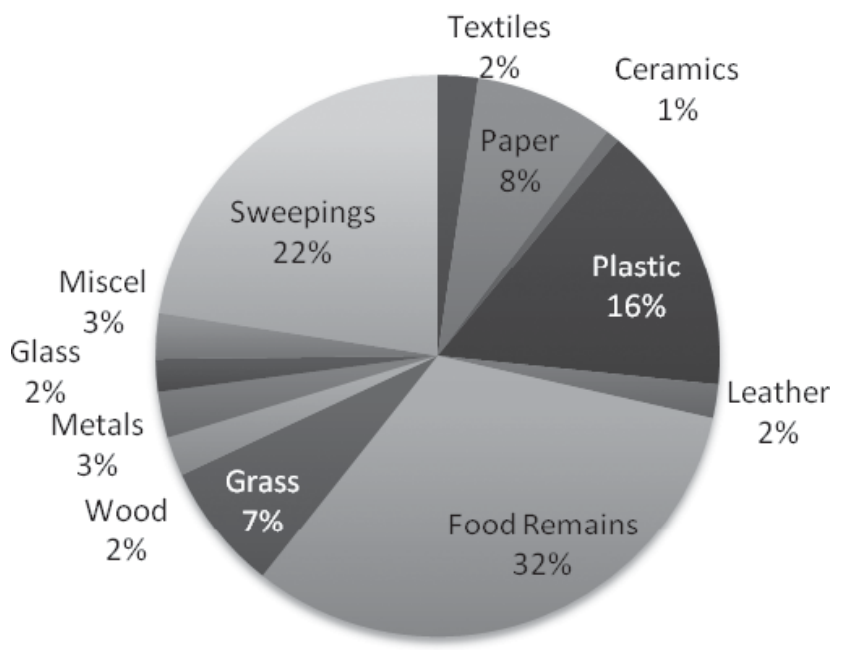

Figure 4: Percentages of waste generated in TAC. 


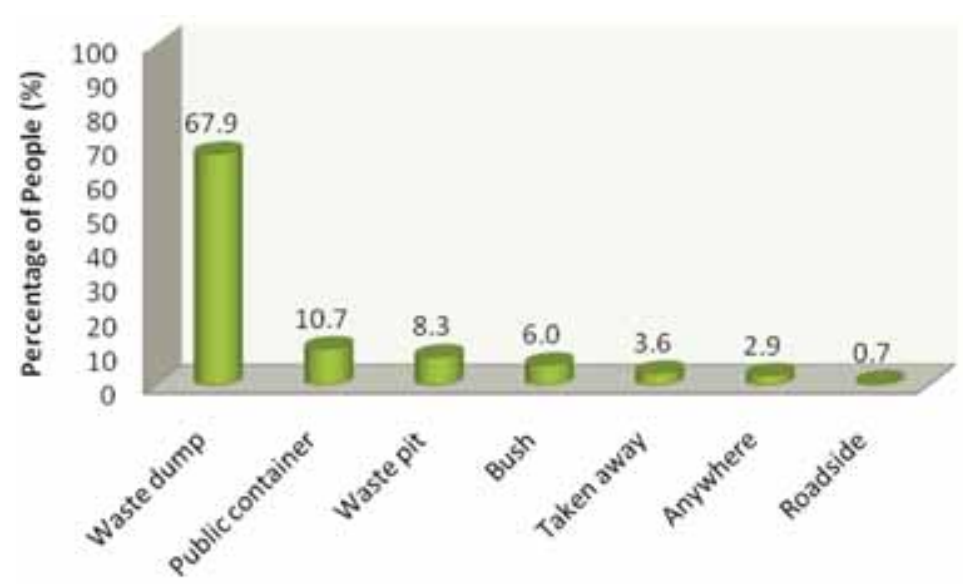

Figure 5: Place of waste disposal.

in public waste containers provided by TNM and Zoomlion Ghana Ltd and $8.3 \%$ in waste pits dugged in individual homes. Approximately $6 \%$ of respondents discard waste into bushes around their homes and business premises, $2.9 \%$ of the people leave it anywhere as shown in Fig. 5.

All respondents from the eight suburbs, namely, Asamanketewa, Boborbo, Bogre, Bokekrom, Brenu Akyemu, Kwabedu, Samahu and Teberebie, did not mention public containers as a disposal point. Field visits to these suburbs comfirmed this. However, a total of $30 \%$ of respondents from Abonti, Atoabo, Tarkwa, Peterson Hill, Taylorkrom and especially Nsuta (76.7\%) discard waste into public containers. The remaning $70 \%$ who also have the public containers at their disposal, discard waste into the bush, by the road side, in waste pits and dumps and anywhere. These observations led to the question whether the waste bins were not enough or whether it was simply a case of societal perception of waste and hence bad waste disposal habits?

\subsubsection{Waste processing at disposal site}

Most respondents (46.9\%) in the municipality burn the waste they generate. About $2.6 \%$ of them burry it and $16.9 \%$ of them do nothing to it (Fig. 6). Suprisingly, 60 people (14.3\% of the sample population), made up of at least one person from each suburb, had absolutely no idea what happens to the waste after disposal. For example, $23.3 \%$ of people in Tarkwa suburb including a town planning officer, a CD seller, a police officer, a bus station officer and three university students did not know what happens to the waste they produce after disposal. Could this be an evidence of an unconcerned public attitude towards waste management?

Burning and burying of waste are normally done monthly mostly by neighbourhood groups, individuals and landlords. In Nsuta, the waste is collected and disposed of by the mining company.

\subsubsection{Waste separation, reuse and sale}

Household waste separation is not a common practice in developing countries [15] and TAC is not an exception. Out of 420 respondents, only 20 people (4.8\%) sort their waste, of which $2.9 \%$ are females.

Most $(37.1 \%)$ of the respondents reuse, $5 \%$ sell and $12.1 \%$ of them allow someone else to pick their plastic waste. About $6.4 \%$ of them reuse food remains as feed for animals or as manure on 


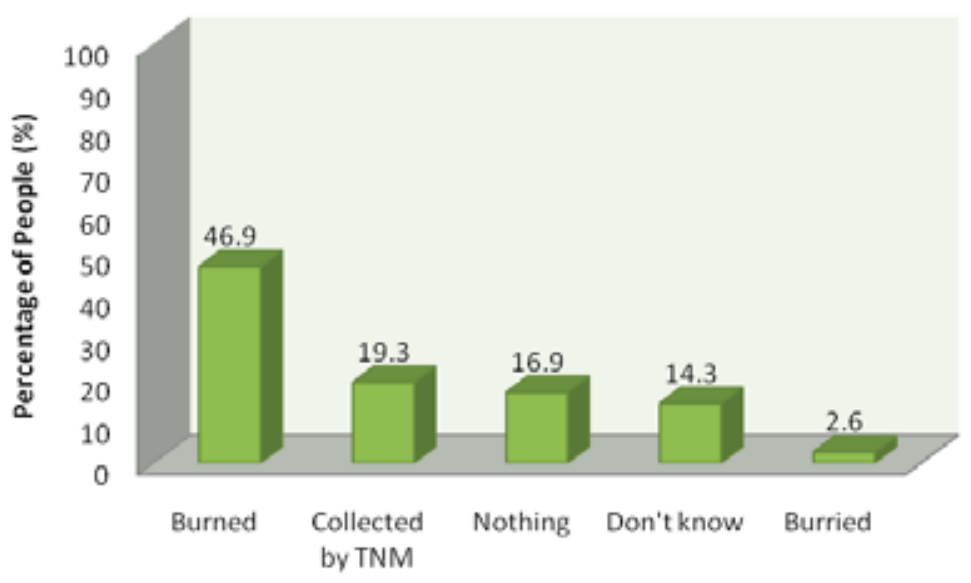

Figure 6: Waste processing method.

farms. About $12.9 \%$ said someone else picks their food remains but nobody sells it. A number of the respondents noted that they reuse, sell and someone else picks their glass waste while about $4.5 \%$ resue their metal cans and $2.4 \%$ sell other metallic wastes to scrap dealers.

\subsubsection{Nearness to waste dump site}

About $41 \%$ of the sample population from all the suburbs live near waste dumps and $23 \%$ are within $50 \mathrm{~m}$ of the dump site. All the respondents including those who do not live near waste dumps believe that the presence of MSW in their locations encourages diseases, breeding of pests and vectors, littering/unsightliness, foul odour and pollution of water sources.

\subsubsection{Payment for waste collection}

About $5 \%$ of respondents from five suburbs, made up of Bogre, Kwabedu, Peterson Hill, Tarkwa and Taylorkrom currently pay between Gh $\phi 2$ and 70 (US\$1.1-36.8) a month for waste collection. Only $30 \%$ of them are willing to pay more Gh $\varnothing 2-12$ (US\$ 1.1-6.3) for better management. Of the $95 \%$ who do not pay for waste collection, 38\% are willing to pay Gh $₫$ 1-60 (US\$ 0.5-31.6) per month for better management. About $82 \%$ of the respondents who are willing to pay and those currently paying prefer to pay it directly as an individual charge. Only $18 \%$ wanted to pay it as part of property tax.

The willingness of the people to pay for better waste management was tested against their income level, level of education and where they lived (suburb). It must be noted that only the $36 \%$ people who stated their monthly income were considered in this test.

Of the three variables tested, only the null hypothesis of the suburbs is rejected. Thus, at 13 degrees of freedom and 5\% level of significance, the theoritical expected value is 22.36 . The Chi-square statistic $\chi^{2}$ calculated from eqn (1) is 99.07; this value is higher than the theoritical expected value and hence the null hypothesis is rejected. Therefore, the respondent's willingness to pay depended only on where they live.

$$
\text { The Chi-square statistic } X^{2}=\sum\left[\frac{\left(O_{i}-E_{i}\right)^{2}}{E_{i}}\right]=99.07
$$




\subsubsection{Health effects of MSW in the neighbourhood}

Improperly managed SWD sites have various health effects on people living near them. In TAC, $82 \%$ of the populace is aware of this fact. Malaria, according to them, is the most prevalent disease in the area as waste dumps serve as breeding ground for the female anopheles mosquitoes, which carry and transmit the malaria parasite. This is followed by cholera, diarrhoea, typhoid and skin diseases in that order. The prevalence of all the diseases in the area as mentioned by the participants was confirmed by some health administrators through interviews.

\subsubsection{Rating of level of MSW management}

The demand for a healthy environment in terms of effective MSW management services resulting in proper sanitation normally increases with increasing socio-economic status of individuals [16]. One approach to solving societal problems is to change the way society thinks about itself. In trying to change the way society thinks about itself, it is first of all necessary to take into consideration the way the society of interest has generated its own values, as a result of the interacting flux of events and ideas unfolding through time [15]. It was therefore necessary to assess or rate the current MSW management system in TAC from the perspective of the respondents. In TAC, a total of $45.5 \%$ of the respondents are not satisfied with the level of waste management in the neighbourhood while $47 \%$ ( $12 \%$ very satisfied and $35 \%$ satisfied) are satisfied. About 30 respondents had difficulty in rating the situation. About $80 \%$ of the respondents are satisfied (23.6\% very satisfied and $56.4 \%$ satisfied) with the level of waste management in their households while $18.3 \%$ are unsatisfied. A total of 14 respondents do not know how to rate the level of waste management in their homes as shown in Fig. 7. Focusing on suburbs closest to mining communities (Nsuta, Ataobo, Samahu and Teberebie), a total of $96.7 \%$ of people from Nsuta and $50 \%$ from Atoabo out of 30 people each are satisfied with the level of MSW management in their communities while all respondents (30 people) in Teberebie and 22 people in Samahu are not satisfied.

On the issue of what can be done to improve the current MSW management system, varying but important ideas came up from all the respondents, though a few from Nsuta thought 'all is well' and hence there is no need for improvement. The most common suggestion was the provision of dust/ waste bins at vantage points throughout the suburbs. This was followed by a need for more public

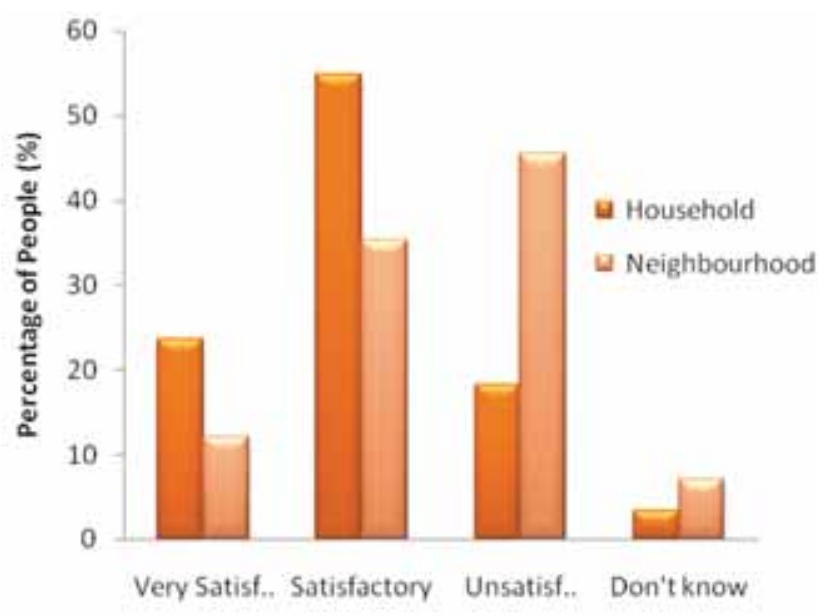

Figure 7: Rating of MSW. 
waste containers and new ones at places without them. The third suggestion was regular waste collection/removal by the authorities. Some respondents believed that organising regular communal labour or clean-up exercises in the communities would solve the problem. Others suggested a need for the construction and operation of a landfill. Public education and law enforcement were also mentioned.

\subsubsection{Field visit and interview with waste management officers from TNM}

An interview with the environmental officers of TNM revealed that ISO 14001 environmental management system is not implemented. However, TNM has an environmental policy in place, objectives and targets for waste collection and disposal in accordance with the Ghana landfills guidelines and the fulfilment of legal requirements such as Metropolitan, Municipal and District Assemblies by-laws. There is also record keeping and competency training for key personal.

According to the environmental officers from the Waste Management Department of TNM, the assembly has 38 waste bins, which are distributed in 22 waste collection points out of about a 100 collection points in TAC. Depending on the rate of waste generation in a particular place, one to three waste bins are placed at a location. For example, the bus station at Tarkwa and the main market have three bins each per day while the railway quarters, a suburb of Bogre, has only one official waste container allotted to it. According to the environmental officers, the assembly has only one waste management vehicle (7-tonne bin capacity). Zoomlion Ghana Ltd has two waste management vehicles (7- and 5-tonne bin capacities) operating in the area. Zoomlion is in charge of 13 waste collection points whist TNM collects waste bins from the remaining nine locations. It was observed during field visits that though the bins are emptied periodically, waste is normally seen around the bins and this attracts pests and vectors and most people prefer to dump waste beside the bin instead of inside it whether the bin is full or empty. The bins at the bus station and the market are disposed every morning from Monday to Saturday. At the other collection points, the bins are emptied every 3 days. There is no sorting at all the collection points.

The final disposal site is located outside TNM at a place called Aboso Nsuaem. The site is not engineered and is basically operated as an open dump; this measure is not in accordance with the Ghana landfills guidelines. The officers also said there is no record keeping at the final disposal site contrary to ISO 14001 standards. There is no sorting at all the collection points but there are scavengers at the final disposal site.

\section{CONCLUSIONS AND RECOMMENDATIONS}

In conclusion, inadequate SWC and unsafe SWD are among the top three major environmental problems faced by the people of TAC. There is no sanitary landfill in TAC and hence at least $41 \%$ of the respondents live within $50 \mathrm{~m}$ of waste dump sites, which are located in every community. According to the residents, these waste dump sites emanate foul odour, the leachate from the dumps pollutes their water resources and causes diseases. Malaria is at the top of the list of diseases caused by the presence of these dump sites in the area, followed by cholera and diarrhoea.

The major MSW type produced in TAC is food remains followed by sweepings and plastics. Majority of the respondents reuse plastic products. Some types of plastics, glass and metals are sold to those who deal in such business to earn a living; however, nobody sells food remains but it is normally collected and used by somebody else.

The most common MSW treatment method in TAC is open fire burning. It is done by the individual waste generator and or neighbourhood groups. The level of satisfaction of waste management depends on where the respondents live in TAC; those who live in suburbs where mining companies collect and transport waste are generally satisfied whereas those who live in 
areas where the municipal assembly collects and transports waste are not satisfied. Therefore, a total of $45.5 \%$ of the people are not satisfied with the level of waste management in their neighbourhoods in TAC.

The following recommendations are made:

1. Easy to use waste bins and more public containers must be provided by the TNM Assembly at vantage points throughout the municipality and must be emptied often by the assembly and private waste providers to prevent overflow.

2. There is a need to construct a sanitary landfill in TNM. The assembly should contract a private waste service providing company to construct and operate the landfill because it is very costly to construct and operate.

3. Public education on the harmful effects of MSW on human health and the environment must be carried out by the environmental department of the TNM Assembly and must involve all other stakeholders such as the waste generator, the community, the Ghana Health Service and private waste service providers. This education campaign must be done before and after the provision of the waste bins and containers to ensure that people do not discard waste indiscriminately anywhere and most importantly inside the containers and not beside it.

4. An environmental task force must be constituted by the assembly to hold people responsible for bad waste management practices.

5. An investment analysis of waste management must be performed by a private waste service provider to consider the possibility of investing in providing waste collection services to the people because some of them are willing to pay for better waste management service.

\section{ACKNOWLEDGEMENT}

I want to extend my profound appreciation to the Tarkwa-Nsuaem Municipal Assembly for supporting this project financially, Professor Ernest Yanful; Department of Civil and Environmental Engineering, University of Western Ontario, Canada for his technical advice and all students of University of Mines and Technology (UMaT) who assisted in the survey.

\section{REFERENCES}

[1] Pfeffer, J.T., Solid Waste Management, Prentice Hall Inc.: New Jersey, 1992.

[2] Lumley, S. \& Armstrong, P., Some of the nineteenth century origins of the sustainability concept. Environment, Development and Sustainability, 6, pp. 367-378, 2004. doi: http:// dx.doi.org/10.1023/B:ENVI.0000029901.02470.a7

[3] Tchobanoglous, G., Theisen, H. \& Vigil, S., Integrated Solid Waste Management, McGraw-Hill, Inc.: Boston, USA, 1993.

[4] Fischer, L. \& Petschow, U., Municipal waste management in Germany. Municipal Waste Management in Europe, eds. N. Buclet \& O. Godard, Kluwer Academic Publishers: London, 2000.

[5] Anon, United nations conference on environment and development (UNCED), Rio de Janeiro, available at http://www.un.org/geninfo/bp/enviro.html retrieved on 17/03/2011, 3-14 June, 1992.

[6] Van Praagh, M. \& Persson, K.M., National translation of the EU landfill directives will landfills become sustainable? International Journal of Sustainable Development and Planning, 1(1), pp 46-60, 2006. doi: http://dx.doi.org/10.2495/SDP-V1-N1-46-60

[7] Perscom., Personal communication with Mr Kpodo, Accra Metropolitan Assembly (AMA) - Waste Management, 2011. 
[8] Anon, ghanadistricts.com, 1990, Retrieved on 12/12/2010.

[9] Kathuri, N.J. \& Pals, D.A., Introduction to Educational Research. Educational Media Centre: Egerton University Njoro, Kenya, 1993.

[10] Anon, ghanaweb.com, 2007, retrieved on 12/12/2010.

[11] Anon, Georgia Statewide Waste Characterisation Study, 2005, Georgia Department of Community Affairs, final Report, $261 \mathrm{p}$.

[12] UNEP, Developing Integrated Solid Waste Management Plan: Waste Characterisation and Quantifications with Projection for Future, Training Manual, United Nations Environmental Programme Division of Technology, Industry and Economics, International Environmental Technology Centre, Osaka/Shiga, Japan, Vol. 1, 77 p, 2009a.

[13] Palczynski, Richard J., Study on solid waste management options, For Africa African Development Bank, 2002, Retrieved on 17/03/2011 from www.bscw.ihe.nl/pub/bscw.cgi/d1354356/SO LID\%2520WASTE\%2520MANAGEMENT\%2520STUDY.pdf.

[14] Babanawo, R., Constraints to sustainable solid waste management in Ghana, PhD Thesis, pp. 87-89, 2006.

[15] Checkland, P., Systems theory and management thinking. The American Behavioural Scientist, 38, 75-91, 1994. doi: http://dx.doi.org/10.1177/0002764294038001007

[16] Inglehart, R., Modernisation and Post-Modernisation: Cultural, Economic, and Political Changes in 43 Societies. Princeton University Press: Princeton, New Jersey, USA, 1997. 